\title{
Analysis Of English Curriculum In 11 Grade Of Udomsasn Wittya School Thailand
}

\author{
Khilayatus Sholihah \\ Udomsasn Wittya School Thailand \\ E-mail: kintan.sari@gmail.com
}

Received: July 10, 2017

Accepted: August 17, 2017

Published: August 31, 2017

dei:10.7575/aiac.ijels.v.1n.1p.1

URL: http://dx.doi.org/10.7575/aiac.ijels.v.1n.1p.1

\begin{abstract}
Curriculum is the device of subjects and educational programs provided by the organizers of an educational institution which contains lesson plans that will be given to participants of lessons over a period of education with certain goals. In this research, the researcher would like to analyze about the English curriculum in 11th grade of Udomsasn Wittya School Thailand. The formulation of the research problems were: 1. How is the curriculum of English Subject at Thailand school designed ? 2. How is the learning course of English Curriculum in Thailand at 11th grade designed ?,3. How is the lesson plan of English Curriculum in Thailand at 11th grade designed ? Research Method: 1) the research design of this research was qualitative content analysis with descriptive qualitative approach. 2) the subject of this research was Thailand Basic Education Core Curriculum B.E. 2551 (A.D. 2008). 3) the data in this research were described and analyzed based on the research questions and the data sources were documents. 4) the technique to collecting the data was content analysis technique. The result of the research showed that Thailand curriculum framework, English syllabus, and the lesson plan were conducted with several common elements of general curriculum based on the theory. The Thailand Curriculum contains the educational environment needs and fulfiled with specific curriculum element and its function and purpose.
\end{abstract}

Key words: curriculum, learning course, lesson plan.

\section{Introduction}

A curriculum can be defined as a plan for action or a written document that includes strategies for achieving desired goals or ends. (Tyler, 1949). Curriculum can be defined as a course of learning activities set out for the learner to perform to make them achieve certain goals prescribed by the educational system. The curriculum generally includes all subjects and activities over which the school has responsibility. It also defines the limits within which certain types of learning are to take place. It denotes those experiences and activities which are devised by the school or other institutions of learning for the purpose of changing a learner's behaviour, acquiring or reinforcing certain skills and preparing him to fit properly into his society (Robinson, 1983).

Based on the statements above curriculum is the device of subjects and educational programs provided by the organizers of an educational institution which contains lesson plans that will be given to participants of lessons over a period of education with certain goals. Setting the course is adjusted to circumstances and the ability of each level of education in the implementation of the education and employment needs. Length of time in the curriculum is usually adjusted with the intent and purpose of the educational system implemented. The curriculum is intended to be directed towards education and the intended purpose in learning activities overall.

A curriculum usually contains a statement of aims and specific objectives. It indicates some selection and organization of content; it either implies or manifests certain patterns of learning and teaching, finally it includes a programme of evaluation of the outcomes ( Taba, 1962 ). Curriculum is all of the educative experience learners have in educational program, the purpose of which is to achieve broad goals and related specific objectives that have been developed within a framework of theory and research, past and present professional practice, and the changing needs of society ( Parkay, 2006 ).

Two main approaches to curriculum design reported by the participating countries are the content or topic-based approach and the outcome-based approach ( NIER, 1999). The content or topic-based approach lists the topics or themes of the subject area or discipline. The listing is generally broad and includes the aims and objectives for the subject area. The outcome-based approach to curriculum design defines the outcomes, usually as abilities or skills, that students are expected to achieve by the end of the period of study or period of schooling for the specific subject. 
In learning second or foreign language, two problems faced by experts and practitioners of curriculum and learning is the adequacy of language exposure and motivation to learn in the language learning process. This issue in the past three decades trying responded by experts and practitioners language curriculum development by introducing an integrated curriculum model in learning foreign languages.

Every country have their own curriculum for learning foreign language. One of country in South East Asia that use English as foreign language is Thailand. Thailand is developing countries which trying on and on to advance their development in every aspect of national life to gain success in this competitive global era. One of the efforts of the nations is developing their human resources through education. Thailand always review, revise or even reform their national curriculums in last years.

The major reform of the English language curriculum in Thailand was introduced in 1999. The 1999 National Education Act lays down guidelines for the provision of education, management of the learning process, and preparation of educational curricula at various levels. The Commission for Basic Education shall be responsible for prescribing the core curriculum for basic education geared towards preserving Thai identity, good citizenship, desirable ways of life and livelihood. It also paves the way for further education. Basic education institutes shall prepare details of the curriculum in part, dealing with community problems, local wisdom, and desirable characteristics of good members of one's community, one's society, and the nation. thus, according to the new curriculum.

English became a compulsory foreign language subject from the first grade. And now, the current Basic Education Core Curriculum 2008 with regard to English as a compulsory subject at the primary school level proposed by the OBEC, the Ministry of Education has been relatively underexplored. It is thus significant for Thai educational policy makers and scholars to engage in strategic English language teaching policies and practices in order to be competitive with the trend for primary level English language education in other ASEAN nations.. The review or the alteration of the curriculum usually covers all subject matters including English.

English is as foreign language (EFL) in Thailand. This EFL position might derive to how is the Thailand English curriculum? This study tries to answer these previous question. To focus the analysis, Thailand Basic Education Core Curriculum B.E. 2551 (A.D. 2008) Curriculum of Foreign Language is selected. The selection is rather subjective, based on researcher's experience background in teaching English at $11^{\text {th }}$ grade Udomsasn Wittya School in Thailand.

Analyzing curriculum is an attempt to breakdown curriculum into its framework elements. The analysis is intended to see how they fit together a whole; to identify the underlying belief and ideas and to examine the implication of the belief for the quality of educational experience and how it implies the educational process ( Posner, 1992 ).

The process of analyzing curriculum can be considered as the reverse process of planning curriculum. In planning curriculum, curriculum developers can follow Tyler (1950) or Johnson (1977) models which have similar procedures: determining what purposes (goals) to attain, what educational experiences to provide (process), how to organize the theme and how to evaluate the purpose (goal) attainment (Posner, 1992). Therefore, the analysis of the English curriculum below is based on the four elements of curriculum above as the framework and added by the underlying belief, approaches, expected teaching process in classrooms and the strength and weaknesses as well.

\section{Literature Review}

\section{Curriculum Definition}

In a sense, the task of defining the concept of curriculum is perhaps the most difficult of all, for the term curriculum has been used with quite different meanings ever since the field took form. Curriculum, however, can be defined as prescriptive, descriptive, or both.

Prescriptive curriculum definitions provide us with what "ought" to happen, and they more often than not take the form of a plan, an intended program, or some kind of expert opinion about what needs to take place in the course of study. (Ellis, 2004, p. 4).

To understand the nature and extent of curriculum diversity, it is important at this study to examine the prescriptive and descriptive definitions offered by some of the past and present leaders in the field. These prescriptive definitions examples, arranged chronologically, have been chosen for their representativeness. Curriculum refers to a written plan outlining what students will be taught (a course of study). Curriculum may refer to all the courses offered at a given school, or all the courses offered at a school in a particular area of study. ( J. L. McBrien \& R. Brandt, 1997 ). Curriculum means the planned interaction of pupils with instructional content, materials, resources, and processes for evaluating the attainment of educational objectives. (n.p.) (Indiana Department of Education , 2010 ).

The descriptive definitions of curriculum go beyond the prescriptive terms as they force thought about the curriculum "not merely in terms of how things ought to be . . but how things are in real classrooms" (Ellis, 2004, p. 5). Another term that could be used to define the descriptive curriculum is experience. The experienced curriculum provides "glimpses" of the curriculum in action.. The definitions provided for prescriptive and descriptive curricula vary primarily in their breadth and emphasis. It would seem that a useful definition of curriculum should meet two criteria: It should reflect the general understanding of the term as used by educators, and it should be useful to educators in making operational distinctions.

Several points in this definition need to be emphasized. First, it suggests that the term curriculum includes both the plans made for learning and the actual learning experiences provided. Limiting the term to the plans made for 
learning is not enough, because, as will be discussed below, those plans are often ignored or modified. Second, the phrase "retrievable documents" is sufficiently broad in its denotation to include curricula stored in a digital form-i.e., software and/or shared on the Internet. Also, those documents, as will be more fully explained below, are of several levels of specificity: Some, such as curricular policy statements, are very general in their formulation; others, such as daily lesson plans, are quite specific. Third, the definition notes two key dimensions of actualized curriculum: the curriculum as experienced by the learner and that which might be observed by a disinterested observer. Finally, the experienced curriculum takes place in an environment that influences and impinges on learning, constituting what is usually termed the hidden curriculum.

Although the definition, for the sake of brevity, does not deal explicitly with the relationship between curriculum and instruction, an implicit relationship does exist. Instruction is viewed here as an aspect of curriculum, and its function and importance change throughout the several types of curricula. First, in the written curriculum, when the curriculum is a set of documents that guide planning, instruction is only one relatively minor aspect of the curriculum. Those retrievable documents used in planning for learning typically specify five components: a rationale for the curriculum; the aims, objectives, and content for achieving those objectives; instructional methods; learning materials and resources; and tests or assessment methods.

\section{Curriculum Frameworks}

One of the most important tools in ensuring consistency and quality in a 'curriculum system' is a 'curriculum framework'. Definition of a curriculum framework is a document (or set of documents) that sets standards for curriculum and provides the context (available resources, capabilities of teachers and system support) in which subject specialists develop syllabuses ( Kigali, Rwanda, 2007 ). A curriculum framework describes the educational environment in which syllabuses (or subject specific outlines of objectives, outcomes, content and appropriate assessment and teaching methodologies) can be developed.

A curriculum framework is most commonly developed at a national level, but a form of curriculum framework could be developed at international level by a group of countries with similar goals and educational environments. One function of a curriculum framework is to define a set of 'curriculum standards' that enable a range of curricula to coexist, on the proviso that each curriculum complies with specific criteria. A curriculum framework is therefore a very useful mechanism for allowing flexibility and diversity among countries within an affiliation of some kind or ethnic groups within a single state. Each individual system can maintain the 'identity' of its own curriculum while ensuring consistency and quality through compliance with a set of agreed standards expressed in the framework.

A curriculum framework commonly contains the elements described in table below. However, one of the advantages of a framework approach is flexibility, and elements can be added to or deleted from the framework structure to suit the needs of the education system or systems developing it.

Element

\section{Introduction:}

Current Context

\section{Function or Purpose}

Describes the social and economic environment in which educational policy is made and in which teaching and learning occur

Describes the Government's goals for education, such as universal literacy and numeracy, the development of skills needed for economic prosperity and the creation of a stable and tolerant society

\section{Statement of Broad Learning Describes what students should know and be able} Objectives and Outcomes / standards for each to do when they complete their school education. level / cycle including knowledge, understanding, skills and competencies, values and attitudes

4.Structure of the Education System Describes the school system within which the curriculum framework is to be applied. It should specify:

- Number of years of schooling, including compulsory schooling durations

- Stages (or cycles) of schooling and their

- Number of weeks in the school years, hours / teaching periods in the school week 


\section{Structure of curriculum content, learning areas and subjects.}

Describes the organization of content within the framework and the extent to which schools and students can make choices. It might describe:

- The pattern of Subjects or Learning Areas to be studied in each stage or cycle (such as core, elective and optional subjects) A brief description of each Subject or Learning Area outlining the rationale for its inclusion in the curriculum and the contribution it makes to the achievement of the Learning Outcomes .

- The number of hours to be assigned to each subject or Learning Area in each stage or cycle.

Describes standards as they apply to:

- Teachers - qualifications, teaching load (number of classes per week)

- Students - number per class in each subject

- Materials - textbooks, computers, other equipment; facilities - classrooms, furniture, fittings.

7. Teaching methodology
might be employed in the implementation of the
framework

To the above list can be added other agreed elements. These could include agreed policies on contentious issues (such as agreed positions on the content of history syllabuses or how history should be taught), how content and student learning can be integrated, the incorporation of competencies or any other matter which requires a 'standard' to be defined.

Once a curriculum framework is agreed, other documents can be developed, including most importantly, subject or learning area syllabuses and textbooks. It is the curriculum framework which gives guidance to syllabus and textbook writers and which determines the detail of a range of other policy and funding priorities.

\section{Quality of Curriculum}

Curriculum is the simplest terms, a description of what, why, how and when students should learn. The curriculum is not, of course, an end in itself. Rather, it seeks both to achieve worthwhile and useful learning outcomes for students, and to realize a range of societal demands and government policies. It is in and through the curriculum that key economic, political, social and cultural questions about the aims, purposes, content and processes of education are resolved. The policy statement and technical document that represent the curriculum reflect also a broader political and social agreement about what a society deems of most worth - that which is of sufficient importance to pass on to its children.

A principal objective of a quality curriculum is, in a fair and inclusive manner, to enable students to acquire and develop the knowledge, skills and values, and the associated capabilities and competencies, to lead meaningful and productive lives. Key indicators of curriculum success include the quality of the learning achieved by students, and how effectively students use that learning for their personal, social, physical, cognitive, moral, psychological and emotional development. A quality curriculum maximizes the potential for the effective enhancement of learning. The premise that educational quality should be understood primarily in terms of the quality of student learning, which in turn depends to a great extent on the quality of teaching. Of prime importance in this is the fact that good teaching and learning are greatly enhanced by the quality, relevance and effectiveness of the curriculum.

Learning in schools occurs of course in a range of intended and unintended ways. Intended learning (frequently referred to as the 'planned' or 'formal' curriculum) most often occurs in the classroom and other 'controlled' settings. Its focus is the 'state-endorsed' curriculum as implemented by teachers. The outcomes of the formal curriculum are normally assessed in various formal ways by teachers and examination authorities.

Unintended learning (such as through the 'hidden' curriculum) can occur anywhere -inside or outside the classroom - and is largely 'uncontrolled'. It can emanate from, for example, the ethos or culture of the school, from unintended features of the intended curriculum (such as gender or cultural bias), from relationships between students and teachers and between students themselves, from societal power structures and existing social arrangements and patterns, from economic, political, social and cultural relationships in the broader society, and, at the broadest level, from how students understand the way things are in their world. If, for example, students see only male teachers in positions of superior authority in their school, they may conclude that positions of power are reserved for men, or that women have a diminished capacity for leadership.

Curriculum is typically a phenomenon which includes many dimensions of learning, including rationale, aims, content, methods, resources, time, assessment, etc; which refers to various levels of planning and decision-making on learning (for example, at the supra-, macro-, meso-, micro- and nano-levels); or, international, national, local, classroom 
and individual levels; and which relates to multiple representations of learning (for example, as already mentioned, 'intended', 'implemented', 'attained', etc). Curriculum can be understood as the totality of what children learn while at school - including what they learn through classroom activities; in interdisciplinary tasks; across the school, for example, in the playground, at lunch time when eating (civic responsibilities, etc.). This curricular totality also includes opportunities for wider achievement through sport, music, debating, and the like. For the purposes of this paper, curriculum is defined in a holistic, process-oriented way. This definition is based on the belief that, while curriculum might commonly be perceived as a set of documents, the quality of those documents is closely connected to the processes used to develop them and to the means through which they are put into practice. In other words, judging the quality of the curriculum itself cannot be done in isolation from the broader processes of curriculum development, implementation and evaluation.

\section{Methods}

This research is using qualitative content analysis. Content analysis is one of qualitative method, this research systematically analyzing written curriculum, syllabus and lesson plans documents and it breaks down lengthy text material into more manageable units of data. The researcher conduct the procedures of content analysis below :

\section{Procedures and Data Collection}

This research adopted a general step by step of a Qualitative Content Analysis by Mayring ( 2014 ) which some procedures towards the research below:

1. The researcher state the research questions. The following problem statements wiill be addressed to stay focus in this reserach and analysis :

a. How is the curriculum of English Subject at Thailand school designed?

b. How is the syllabus of English Curriculum in Thailand at 11th grade designed?

c. How is the lesson plan of English Curriculum in Thailand at 11th grade designed?

2. The researcher select the materials ( document) for being analyze. The selected materials are :

a. The Thailand Basic Education Core Curriculum B.E. 2551 (A.D. 2008) English as foreign language curriculum .

b. The English subject syllabus of 11th grade of Udomsasn Wittya School in one term period of semester.

c. Two sample of lesson plan according to the English syllabus of $11^{\text {th }}$ grade.

3. The researcher read and review the materials (those three documents of curriculum, syllabus, and lesson plan).

4. The researcher defines the unit of analysis categories for each materials. It will breakdown into categories to being analyze.

5. The researcher analyzing the materials for each category by applying it to the literature reviews towards the curriculum policy in previous chapter.

6. Interpreting the findings and report the result of analysis into description of content-analytical quality criteria

Source of Data

The data sources are the written script of English subject Thailand Basic Education Core Curriculum B.E. 2551 (A.D. 2008), written script of syllabus in 11th grade of Udomsasn Wittya School document, and written script of lesson plan.

Research Instrument

Document

Document is the only instrument of this research, the researcher collecting data is obtained through documents. The document is primary source for the researcher analyze the data.

Data Analysis

The data analysis technique is using the content analysis theory, this will analyse each problem statement step by step.

1. Problem statement number one : How is the curriculum of English Subject at Thailand school designed ?

a. The researcher read the document of Thailand English Curriculum 11th grade of senior high school.

b. Focus at the categories that will be analyse.

c. Analyze by corelates the content toward the literature review and theory.

d. Intepretnig the findings into description of analysis paragraph.

2. Problem statement number two : How is the syllabus of English Curriculum in Thailand at 11th grade designed? 
a. The researcher read the document of Thailand English syllabus 11th grade of senior hgh school in one term period of semester.

b. Focus at the categories that will be analyse.

c. Analyze by corelates the content toward the literature review and theory.

d. Intepreting the findings into description of analysis paragraph.

3. Problem statement number three : How is the lesson plan of English Curriculum in Thailand at 11th grade designed?

a. The researcher read the two sample documents of Thailand English lesson plan 11th grade of senior high school according to the syllabus.

b. Focus at the categories that will be analyze.

c. Analyze by finding the content toward the literature review and theory.

d. Intepreting the findings into description of analysis paragraph.

\section{Findings}

In this chapter the researcher analyse the contents of the document curriculum, syllabus and lesson plan for results of the study. Based on the Thailand curriculum and syllabus along with lesson plans from Udomsasn Wittya School the researcher obtained the data related to this study, the next step researcher is trying to analyse the documents which became the object of research, the data will be corelates toward the theory of experts and curriculum policy itself. Based on the problem statements, in this case the researchers focused on how is the content of curriculum, syllabus and lesson plan designed. The results of this analysis on these three documents are below :

\section{Analysis of the English Curriculum}

The Thailand basic core curriculum is qualified according to those eight common elements of curriculum. Because the eight elements covered by the Thailand basic core curriculum contents. And the researcher also found another finding about the Thailand basic core curriculum content. Thailand also set some desired characteristic elements which enable learners to enjoy their lives as Thai citizens and global citizens to attainted and focused the learners' development through the curriculum as follows ; love of nation, religion, and the monarchy, honesty and integrity, selfdiscipline, avidity for learning, applying principles of Sufficiency Economy Philosophy in one's way of life, dedication and commitment to work, cherishing Thai nationalism, and Public-mindedness. Thailand needs the desired characteristic to strengthen the national education goal beyond the common elements of the general curriculum.

\section{Analysis of the English Syllabus/Learning Course}

The school English syllabus is not qualified enough according to those six common elements of syllabus. Because not all of the six elements covered by the Thailand basic core curriculum contents appropriately. One of the incomplete element was course description and objectives, the school syllabus should contain this element, that would be describe the general content of the school syllabus, the instructional method and course goals. And the researcher also found another finding about the Thailand English syllabus content. The English syllabus contain of range of score in every learning topic. These scores should be gained by the students in learning activity. It help the teacher managed their teaching attaintment in period of time to process and fulfiled the students' report.

\section{Analysis of the English Lesson Plan}

The English lesson plan was condunted with common elements of lesson plan according to Brown, H. Douglas (2001), A good lesson plan is an important tool that focuses both the instructor and the learners on the purpose of the lesson and, if carefully constructed and followed, enables learners to efficiently meet their goals. The school lesson plan conducted with some stages according to the theory. And already covered the teaching-learning needs for the students and teacher.

\section{Discussion}

Based on Thailand Basic Education Core Curriculum B.E. 2551 (A.D. 2008), the curriculum framework was conducted through several common curriculum framework elements according to Kigali Rwanda ( 2007 ). Thailand set briefly the common elements of curriculum framework appropriate with their social economic and cultural background. Stage by stage of the elements fulfilled the country needs of the knowledge in nowdays. The rapid change of the economic social together with scientific and technological, made Thailand maximizes the potential for the effective enhancement of learning through their curriculum. It's possible to Thailand for enhancing the curriculum in the next future to keep in balance with the needs of the era of globalization.

The English syllabus / learning course topic in 11th grade of Udomsasn Wittya School was conducted with common elements of syllabus. According to Howard B. Altman, and William E. Cashin (1992), the school syllabus elements conducted more in simply form than the theory itself. Not all of the content of the element in the school syllabus clearly written. But the school syllabus already covered the curriculum by conducted as well as their needs. 
Based on the researcher findings, the English lesson plan was condunted with common elements of lesson plan according to Brown, H. Douglas (2001), A good lesson plan is an important tool that focuses both the instructor and the learners on the purpose of the lesson and, if carefully constructed and followed, enables learners to efficiently meet their goals. The school lesson plan conducted with some stages according to the theory. And already covered the teachinglearning needs for the students and teacher.

\section{Conclusion}

There are three conclusions since the researcher stated three statements of the research problem. They were: (1). How is the curriculum of English Subject at Thailand school designed, (2). How is the syllabus of English Curriculum in Thailand at 11th grade designed, and (3). How is the lesson plan of English Curriculum in Thailand at 11th grade designed .

The Analysis of English Curriculum

The first problem statement is answered by the analysis of Thailand English Curriculum. The researcher conclude that the design of Thailand Curriculum framework conducted with several common elements of general curriculum based on the theory. The Thailand Curriculum contains the educational environment needs and fulfiled with specific curriculum element and its function and purpose. In the aim to gained the systematic curriculum design for educational policy. It's qualified curriculum which maximizes the potential for the effective enhancement of learning. The premise that educational quality should be understood primarily in terms of the quality of student learning, which in turn depends to a great extent on the quality of teaching. The prime importance in this is the fact that good teaching and learning are greatly enhanced by the quality, relevance and effectiveness of the curriculum.

\section{The Analysis of Syllabus / Learning Course}

The second problem statement is answered by the analysis of the English syllabus of 11th grade of Udomsasn Wittya School. The researcher conclude that the design of syllabus conducted with several common elements of general syllabus based on the theory. The school syllabus contains the educational environment needs and fulfiled with specific syllabus element and its function and purpose.

The syllabus contained an outline, and a schedule of topics, and many more items of information. With the primary purpose is to communicate to one's students what the course is about, why the course is taught, where it is going, and what will be required of the students for them to complete the course with a passing grade.

The Analysis of Lesson Plans

The third problem statement is answered by the analysis of the lesson plan content of towards the curriculum policy. Based on the research finding the researcher conclude that the design of lesson plan conducted with several common elements of general lesson plan based on the theory. It's good lesson plan with important tool that focuses both the instructor and the learners on the purpose of the lesson and, if carefully constructed and followed, enables learners to efficiently meet their goals. The lesson is a set of activities that focuses on one teaching objective at a time. The teaching objective states what the learners will be able to do at the end of the lesson.

\section{References}

Akdemir, Esma Nur Karamese, Ali Arslan (2014) Descriptive Analysis Of Researches On Curriculum Development In Education.

Allan S. Mackenzie ( 2011 ) : EFL curriculum reform in Thailand.

Amporn Ratanavipak, Analysis Of The Basic Education Curriculum In Thailand.

Andre Yuris, 2009 , Berkenalan Dengan Analisis Isi (Content Analysis)

Aynur Yürekli PhD ; An Analysis Of Curriculum Renewal In EAP Context, 2012.

Brown, H. D. (2001). Teaching by principles: An interactive approach to language pedagogy. Englewood

Cliffs, NJ: Longman.

Cecilia Braslavsky 1999, The Curriculum.

Elizabeth Kennedy ( 2014 ) : A look at the 2013 Curriculum. 
Glenn A. Bowen (2009) ; Document Analysis as a Qualitative Research Method

Howard B. Altman, and William E. Cashin,( 1992 ) : Writing Syllabus.

Jay Parkes and Mary B. Harris, 2002, The Purposes of a Syllabus

John Brown, Ed. D. University of Massachusetts :Four Components of a Lesson Plan

Jonathan D Jansen Vijay Reddy, 1994, Curriculum Analysisa reference manual

Kasetsart J. (Soc. Sci) 34 : 583 - 589 (2013) ; Review of English Language Basic Education Core

Curriculum: Pedagogical Implications for Thai Primay Level Teachers of English

Kigali, Rwanda 2007 UNESCO-IBE : What basic education for Africa?

Mayring ( 2014 ) ; A General Step By Step Of A Qualitative Content Analysis

National institute for educational research ( NIER, 1999) : An International Comparative Study of School Curriculums .

Office of the Basic Education Commission. (2008).Basic education core curriculum B.E. 2551 (A.D.

2008). Bangkok: Ministry of Education.

Office of the Education Council. (2009). Proposals for the second decade of education reform. Bangkok: Office of the Education Council.

Rebecca Reynolds 2009 , Curriculum Analysis: Creative Curriculum

Silalahi, Ulber. 2009. Metode Penelitian Sosial

Stabback, P (2007). Guidelines for Constructing a Curriculum Framework for Basic Education.

Suhar ( 2013 ) : Reviewing School-Based Curriculum to Succeed the 2013 Curriculum.

Sulistyo-Basuki. 2006. Metode Penelitian. Jakarta: Wedatama Widya Sastra. 